\title{
Comparative Evaluation of the Nutrient Composition and Phytochemical Content of Selected Vegetables Consumed in Nigeria
}

\author{
A.N. Ukom ${ }^{*}$ and J.A. Obi \\ Department of Food Science and Technology, Michael Okpara University of Agriculture, \\ P.M.B 7267, Umudike, Nigeria \\ tony2008gospel@gmail.com
}

Keywords: Nigeria, Selected vegetables, Nutrient composition, Phytochemical composition

\begin{abstract}
This study evaluated the phytochemical and nutrient composition of four selected vegetables consumed in Nigeria, namely, bush mallow (ahihara), garden egg leaf (okpokwa), African spinach (inine), and bush okro (ewedu). They were analyzed for proximate, minerals, vitamins and phytochemical contents. Proximate values maintained the following ranges: moisture $6.73 \%$ to $91.22 \%$, protein $7.05 \%$ to $32.12 \%$, crude fiber $2.75 \%$ to $6.36 \%$, ether extract $3.15 \%$ to $6.81 \%$, ash content $2.81 \%$ to $6.81 \%$ and carbohydrate $48.75 \%$ to $72.62 \%$, while energy value ranged from $340.54 \mathrm{kcal}$ to $363.07 \mathrm{kcal}$. The vitamin content for these vegetables ranged as follows: vitamin A $0.13 \mathrm{mg} / 100 \mathrm{~g}$ to $370.64 \mathrm{mg} / 100 \mathrm{~g}$, thiamin (vit $\mathrm{B}_{1}$ ) $3.12 \mathrm{mg} / 100 \mathrm{~g}$ to $7.45 \mathrm{mg} / 100 \mathrm{~g}$, riboflavin (vit $B_{2}$ ) $0.08 \mathrm{mg} / 100 \mathrm{~g}$ to $3.96 \mathrm{mg} / 100 \mathrm{~g}$, vitamin $\mathrm{B}_{3}$ (niacin) $0.17 \mathrm{mg} / 100 \mathrm{~g}$ to $1.91 \mathrm{mg} / 100 \mathrm{~g}$, and vitamin $\mathrm{C} 39.84 \mathrm{mg} / 100 \mathrm{~g}$ to $98.75 \mathrm{mg} / 100 \mathrm{~g}$. The mineral content, namely, calcium ranged from $45.61 \mathrm{mg} / 100 \mathrm{~g}$ to $430.69 \mathrm{mg} / 100 \mathrm{~g}$, magnesium $11.05 \mathrm{mg} / 100 \mathrm{~g}$ to $198.14 \mathrm{mg} / 100 \mathrm{~g}$, potassium $49.82 \mathrm{mg} / 100 \mathrm{~g}$ to $708.28 \mathrm{mg} / 100 \mathrm{~g}$, sodium $2.36 \mathrm{mg} / 100 \mathrm{~g}$ to $22.98 \mathrm{mg} / 100 \mathrm{~g}$. Also the phytochemical content of the vegetables for phytate ranged from $0.47 \mathrm{mg} / 100 \mathrm{~g}$ to $3.04 \mathrm{mg} / 100 \mathrm{~g}$, tannin from $0.10 \mathrm{mg} / 100 \mathrm{~g}$ to $1.01 \mathrm{mg} / 100 \mathrm{~g}$, saponin from $0.16 \mathrm{mg} / 100 \mathrm{~g}$ to $2.56 \mathrm{mg} / 100 \mathrm{~g}$ and oxalate from $0.63 \mathrm{mg} / 100 \mathrm{~g}$ to $0.72 \mathrm{mg} / 100 \mathrm{~g}$. Result obtained from these vegetables show that they can contribute qualitatively to the nutritional need of the Nigerian population, especially among the rural dweller where vegetables are major food source.
\end{abstract}

\section{Introduction}

Vegetables are edible parts of leaf, stem and roots of plant [1]. They are usually cooked or eaten raw. They include those plant parts that are used in making soup which serve as an integral part of the people's meal [2]. As a food source, they supply fiber, minerals and vitamins to the diet of majority of people in the developing countries, where they are frequently consumed as side dish or relish with staple foods [3]. Vegetables are important protective food for the maintenance of health and prevention of diseases. They contain valuable phyto-nutrients like carotenoids, polyphenolic compounds and dietary fibre that can be utilized for the physiological needs of the body and inhibit disease conditions such as cancer, heart attack, stroke, hypertension, birth defects, cataracts and diabetes. Edible vegetables are grouped into leafy vegetables (lettuce), stem vegetables (asparagus), root vegetables (carrot), flower vegetables (broccoli) and bulbs (garlic and onions). Certain fruits such as tomatoes and beans are used as vegetables [4]. They may grow wild or cultivated as trees, herbs, shrubs or erect plants that cut across the plant world.

In Africa, and especially Nigeria, green leafy vegetables are consumed as soup complements of major staples like cassava, cocoyam, guinea corn, yam, maize, millet, rice and unripe plantain. Vegetables contribute to food security and add spice and variety to the starchy staples either as soups or porridge. In fact, eating these staples is considered incomplete without a generous serving of cooked vegetables. Broadly, green leafy vegetables are good sources of micronutrients, nonvolatile acids, organic acids, mineral salts, volatile sulphur compounds and tannin, which impart flavor in diets and antioxidant compounds like polyphenols, flavonoids and arrays of carotenoids especially, $\beta$-carotene and ascorbic acid which boost the body immunity [5]. Vegetables also consist of carbohydrates mainly as indigestible fibrous materials such as cellulose, hemicelluloses and 
lignin and small quantities of sugars such as glucose, fructose, sucrose and high moisture content that ranges from $75 \%$ to $95 \%$.

The micronutrient content of leafy vegetables can potentially address the problem of micronutrient deficiency among the rural dwellers in Nigeria. In contribution to health, reasonable amount of vegetable intake has been reported to reduce the risk of degenerative diseases like cancer, diabetis mellitus and cardiovascular diseases [6].

The major anti-nutrients in green leafy vegetables are phytic and oxalic acids. These are important because of their significant adverse effect on nutritional value of vegetables [5]. High level consumption of either phytate or oxalate from plant foods inhibits the absorption and utilization of minerals especially iron, zinc and calcium. Pamploma-Rogers [7] stated that fruits and vegetables have been linked to the management of anemia, because they are rich in vitamins and minerals. In Nigeria, especially among the rural population, there is limited information on the nutrient profile of staple vegetables, which are abundant during the rainy season (and are consumed in large amount), but are scarce in the dry season. This situation can lead to protein and micronutrient deficiency among the rural population. Information and advocacy on the nutritional value of vegetables will go a long way to guide consumers on the choice of vegetables to use for food preparation, since different kinds of vegetables are readily available in every locality, especially during the rainy season. This study will add information on the nutrient and anti-nutrient composition of vegetables grown and consumed in Nigeria for use especially by researchers and consumers of vegetables for improved nutrition. In this study, we investigated the chemical and anti-nutritional composition of some staple vegetables consumed in Nigeria, as a major objective.

\section{Materials and Methods}

Vegetable materials: The vegetables used in this study were obtained from a farm in Obingwa LGA, Abia State and Oyingbo Market, Lagos State, Nigeria. They were identified by the University Herbarium of Michael Okpara University of Agiculture, Umudike.

Clean black polyethylene bags were used to collect and store the vegetable samples in a refrigerator to avoid heat, contamination and wilting for a day prior to processing. Table 1.

The local names, botanical names, common names and parts of the plant used are listed in

Table 1. Staple vegetables, names and parts used

\begin{tabular}{|c|c|c|c|}
\hline Local names & Botanical names & Common names & Parts of the plant \\
\hline 1 Ahihara (Igbo) & Corchorus capsularis & Bush mallow & Vegetable \\
\hline $\begin{array}{l}2 \text { Okpokwa or } \\
\text { Anara (Igbo) }\end{array}$ & Solanium macrocarpon & $\begin{array}{l}\text { Giant garden } \\
\text { egg leaf }\end{array}$ & Vegetable \\
\hline 3 Inine (Igbo) & Amaranthus hybridus & $\begin{array}{l}\text { African spinach } \\
\text { or Green }\end{array}$ & Vegetable \\
\hline 4 Ewedu (Yoruba) & Corchorus olitorius & Bush okro & Vegetable \\
\hline
\end{tabular}

The vegetable leaves were handpicked to remove unwanted materials. They were washed with clean tap water and were allowed to drip off on a perforated tray. Edible portions of the vegetables were sliced and oven dried at $50{ }^{\circ} \mathrm{C}$. They were cooled and milled into powder with a local attrition mill and then stored in an air tight container for subsequent use.

\section{Chemical analysis}

The proximate analysis: moisture, crude protein, crude fat, fibre and carbohydrate (by difference) were determined by the methods of AOAC [8]. Energy content was determined by the method of Kanu et al. [9]. They mineral elements: calcium and magnesium content of the samples was carried out by versanate EDTA complexiometric titration described by James [10]. Flame photometry was used to determine the concentration of potassium and sodium as described by James [10]. Vitamin 
A, thiamine (B1), riboflavin (B2), niacin (B3) and vitamin C content of each vegetable sample was determined by the method of AOAC [8]. Phytate was determined by the method described by Oberlease [11], while the method described by Obadoni and Ochuko [12] was used to determine the saponin content. Tannin was determined by the method of Pearson [13] and oxalate content was determined using the method of Iwuoha and Kalu [14].

\section{Results and Discussion}

Proximate composition of vegetables

\section{Data Analysis}

Mean and standard deviation were calculated for triplicate determinations using the Statistical Package for Social Sciences (SPSS) version 10 Statistic Software Package. Data were expressed as mean \pm standard deviation (SD). Comparisons between groups were performed with analysis of non-parametric test. A value of $\mathrm{P}<0.05$ was considered statistically significant.

Table: 2 show the result of the proximate composition of the vegetables. The percentage dry matter varied from $91.22 \%$ to $93.27 \%$. The highest value was obtained in garden egg leaf (93.27\%), while the least was obtained in African spinach leaf (91.22\%). Percentage moisture content ranged from $6.73 \%$ to $8.78 \%$ with the highest value obtained in African spinach and the least value recorded in the garden egg leaf.

Table 2. Proximate composition of some vegetables consumed in Nigeria (\%)

\begin{tabular}{|c|c|c|c|c|c|c|c|c|}
\hline Sample & Dry matter & Moisture & $\begin{array}{l}\text { Crude } \\
\text { protein }\end{array}$ & Crude fibre & Crude fat & Ash & Carbohydrates & $\mathrm{Ev}(\mathrm{k} / \mathrm{cal})$ \\
\hline $\begin{array}{l}\text { Bush } \\
\text { mallow }\end{array}$ & $91.70^{\mathrm{c}} \pm 0.14$ & $8.30^{\mathrm{a}} \pm 0.14$ & $7.05^{\mathrm{d}} \pm 0.03$ & $4.81^{\mathrm{b}} \pm 0.04$ & $4.02^{\mathrm{a}} \pm 0.01$ & $3.21^{\mathrm{c}} \pm 0.01$ & $72.62^{\mathrm{a}} \pm 0.12$ & $=0.72$ \\
\hline $\begin{array}{l}\text { G. Egg } \\
\text { Leaf }\end{array}$ & $93.27^{\mathrm{a}} \pm 0.33$ & $6.73^{c} \pm 0.33$ & $32.12^{\mathrm{a}} \pm 0.02$ & $2.75^{\mathrm{d}} \pm 0.03$ & $2.85^{\mathrm{d}} \pm 0.49$ & $6.81^{\mathrm{a}} \pm 0.01$ & $48.75^{\mathrm{d}} \pm 0.36$ & $349.05^{\mathrm{c}} \pm 1.21$ \\
\hline $\begin{array}{l}\text { Afr. } \\
\text { Spinach }\end{array}$ & $91.22^{\mathrm{c}} \pm 0.14$ & $8.78^{\mathrm{a}} \pm 0.04$ & $15.53^{\mathrm{c}} \pm 0.03$ & $6.36^{\mathrm{a}} \pm 0.03$ & $3.72^{\mathrm{b}} \pm 0.03$ & $4.35^{\mathrm{b}} \pm 0.03$ & $61.24^{\mathrm{b}} \pm 0.02$ & $340.54^{\mathrm{d}} \pm 0.23$ \\
\hline $\begin{array}{l}\text { Bush } \\
\text { okro }\end{array}$ & $92.55^{\mathrm{b}} \pm 0.21$ & $7.45^{\mathrm{b}} \pm 0.21$ & $24.40^{\mathrm{b}} \pm 0.01$ & $2.91^{\mathrm{c}} \pm 0.04$ & $3.15^{\mathrm{c}} \pm 0.04$ & $2.81^{\mathrm{d}} \pm 0.01$ & $58.28^{\mathrm{c}} \pm 0.10$ & $363.07^{\mathrm{a}} \pm 0.83$ \\
\hline
\end{tabular}

Values are mean \pm standard deviation of duplicate deviations. Data with the same superscripts along the same row are not significantly different at $(\mathrm{P} \geq 0.05)$. N/B Ev $=$ Energy value

Crude protein of the vegetables ranged from $7.05 \%$ to $32.12 \%$. Garden egg leaf was the highest value. These findings are in agreement with the values of $20.5 \%$ in Amaranthus caudatus and $13.1 \%$ in Lesianthera africanas reported by other researchers [15-17]. Protein is vital for growth, maintenance and repair of worn out tissues. It is known that animal protein is expensive and the use of vegetable source to supply cheap protein especially among the rural poor population in developing country such as Nigeria cannot be over-emphasized. The results show that these vegetables especially garden egg leaf (Okpokwa) are good sources of protein. Thus, the protein content of these vegetables will go a long way in meeting the protein need of the rural poor who supplement their food with vegetables.

The highest percentage crude fiber was obtained in African spinach (6.36\%), while the least was recorded in the garden egg leaf (2.75\%). These values are in accordance with the report of Akindahunsi and Salawu [18] and Anita et al. [19] in percentage crude fiber of P.guineensis (6.4\%) and corchorus olitorius (7.0\%). Dietary fiber is important in intestinal health and in prevention of excess cholesterol absorption. Dietary fibre, mainly cellulose and hemicellulose add bulk to the diet, ease waste elimination and prevent absorption of excess starchy diets which protects metabolic conditions against hypercholesterolemia, diabetes mellitus [20] and other related health complications. 
Percentage crude fat shows a significant difference in the vegetables. The values obtained in this study $(2.85 \%$ to $4.02 \%)$ are higher than those reported on raw and cooked $T$. triangulare $(1.14 \%$ and $1.08 \%)$ by Eleazu and Eleazu [21].

The highest ash content (6.81\%) was recorded in garden egg leaf while the least $(2.81 \%)$ was recorded in African spinach. This is in agreement with the findings of Mofunanya et al. [22].The ash content is indicative of the mineral content of the leafy vegetables.

This study shows that these vegetables contain significant quantities of carbohydrates. The values ranged from $48.75 \%$ to $72.62 \%$ with the highest content obtained in bush mallow while the least was observed in garden egg leaf. The carbohydrate content of bush mallow was significantly $(p<0.05)$ higher when compared to other vegetables.

Energy values showed that bush okro was highest while African spinach had the least. Vegetables are low energy food and can be used as slimming diet.

Vitamin composition of vegetables

Table 3. Vitamin Composition of Vegetables (mg/100g)

\begin{tabular}{lccccc}
\hline Sample & Vitamin A & Vitamin $_{1}$ & Vitamin $_{2}$ & Vitamin $B_{3}$ & Vitamin C \\
\hline Bush mallow & $0.13 \pm 0.04^{\mathrm{d}}$ & $7.45 \pm 0.08^{\mathrm{a}}$ & $0.08 \pm 0.01^{\mathrm{d}}$ & $0.74 \pm 0.01^{\mathrm{b}}$ & $98.73 \pm 0.04^{\mathrm{a}}$ \\
& & & & & \\
Garden egg leaf & $370.64 \pm 0.05^{\mathrm{a}}$ & $5.73 \pm 0.03^{\mathrm{b}}$ & $0.21 \pm 0.00^{\mathrm{c}}$ & $0.17 \pm 0.01^{\mathrm{c}}$ & $39.84 \pm 0.01^{\mathrm{d}}$ \\
African spinach & $46.13 \pm 0.04^{\mathrm{b}}$ & $3.57 \pm 0.08^{\mathrm{c}}$ & $0.28 \pm 0.03^{\mathrm{b}}$ & $0.75 \pm 0.02^{\mathrm{b}}$ & $49.69 \pm 0.02^{\mathrm{b}}$ \\
Bush okro & $4.02 \pm 0.01^{\mathrm{c}}$ & $3.12 \pm 0.03^{\mathrm{d}}$ & $3.96 \pm 0.01^{\mathrm{a}}$ & $1.91 \pm 0.03^{\mathrm{a}}$ & $43.83 \pm 0.06^{\mathrm{c}}$
\end{tabular}

Values are mean \pm standard deviation of duplicate determinations. Means with the same super scripts within the same row are not $(\mathrm{P}>0.05)$ significantly different.

The vitamin content of these vegetables is shown in Table 3. The vitamin A content ranged from $0.13 \mathrm{mg} / 100 \mathrm{~g}$ to $370.64 \mathrm{mg} / 100 \mathrm{~g}$. Vitamin A content of garden egg leaf was significantly $(\mathrm{p}<0.05)$ higher than that of other vegetables. The values are within the range reported by Okwu and Josiah [23] for Aspilla africana, V. amygdalina, Bryophylum pinnatum and O. gratissium K. From the data on vitamin A, consumption of adequate quantity of these vegetables can boost daily requirement of vitamin A for humans. Vitamin A as an antioxidant is known to scavenge free radicals in the body and thus prevents cellular damage. It is important in maintenance of healthy eyes and skin, normal growth and reproduction as well as enhancement of immune function [24].

The thiamine content of these vegetables ranged from $3.12 \mathrm{mg} / 100 \mathrm{~g}$ to $7.45 \mathrm{mg} / 100 \mathrm{~g}$. Bush mallow was significantly higher while African spinach was the least. These values are within the range reported by Akubugwo et al. [25]. Thiamine is required for the maintenance of nerve tissue and for the release of energy from carbohydrate metabolism [26].

Vitamin $\mathrm{B}_{3}$ (riboflavin) content of the vegetables range from $0.08 \mathrm{mg} / 100 \mathrm{~g}$ to $3.96 \mathrm{mg} / 100 \mathrm{~g}$, with the highest content obtained in African spinach while the least was found in bush mallow.

The values are in agreement with the finding of Akubugwo et al. [25] on the nutritional and chemical analysis of amaranthus hybridus, but lower than the value $(0.94 \mathrm{mg} / 100 \mathrm{~g})$ reported by Ifon and Bassir [27] in some Nigerian leafy vegetables with the exception of African spinach $(3.96 \mathrm{mg} / 100 \mathrm{~g})$. Riboflavin is a vitamin that helps in the regulatory functions of some hormones that connect with carbohydrate metabolism.

Niacin (vitamin $B_{3}$ ) content of the vegetables varied from $0.17 \mathrm{mg} / 100 \mathrm{~g}$ to $1.91 \mathrm{mg} / 100 \mathrm{~g}$. The bush mallow had the highest niacin content while garden egg leaf was the least.

The ascorbic acid content of these vegetables varied from $39.84 \mathrm{mg} / 100 \mathrm{~g}$ to $98.73 \mathrm{mg} / 100 \mathrm{~g}$. The highest concentration was recorded in bush mallow, while the least was in garden egg leaf. These values are higher than the value $(29.37 \mathrm{mg} / 100 \mathrm{~g})$ reported by Sobowale et al. [6] in some 
leafy vegetables consumed in Nigeria. Vitamin $\mathrm{C}$ is essential for healthy teeth, gum and bone. It is also vital for proper functioning of the adrenal and thyroid glands. Scurvy is a deficiency disease of vitamin $\mathrm{C}$ and adequate intake of ascorbic acid from these vegetables can be used in the curing of scurvy and also can reduce the formation of carcinogenic nitrosamines [28]. The results show high concentrations of vitamins $\mathrm{A}$ and $\mathrm{C}$, riboflavin, thiamine and niacin, enough to meet the Recommended Daily Allowance of $90 \mathrm{mg}$ /day vitamin $\mathrm{C}$ and $1.3 \mathrm{mg} /$ day of riboflavin. These vegetables are therefore important in ameliorating micronutrient malnutrition that is encountered among Nigeria's urban and rural dwellers.

Mineral composition of vegetables

The mineral composition of the vegetables is shown in Table 4.

Table 4. Mineral composition of vegetables (mg/100g)

\begin{tabular}{ccccc}
\hline Samples & $\mathrm{Ca}$ & $\mathrm{Mg}$ & $\mathrm{K}$ & $\mathrm{Na}$ \\
\hline Bush mallow & $430.69 \pm 0.01^{\mathrm{a}}$ & $148.92 \pm 0.01^{\mathrm{b}}$ & $220.03 \pm 0.03^{\mathrm{b}}$ & $2.36 \pm 0.03^{\mathrm{d}}$ \\
Garden egg leaf & $209.61 \pm 0.04^{\mathrm{c}}$ & $11.05 \pm 0.02^{\mathrm{d}}$ & $708.28 \pm 0.04_{\mathrm{a}}$ & $22.98 \pm 0.01^{\mathrm{a}}$ \\
African spinach & $241.39 \pm 0.01^{\mathrm{b}}$ & $120.55 \pm 0.02^{\mathrm{c}}$ & $210.02 \pm 0.03^{\mathrm{c}}$ & $3.83 \pm 0.03^{\mathrm{c}}$ \\
Bush okro & $45.61 \pm 0.01^{\mathrm{d}}$ & $198.14 \pm 0.04^{\mathrm{a}}$ & $49.82 \pm 0.02^{\mathrm{d}}$ & $7.14 \pm 0.01^{\mathrm{b}}$ \\
\hline
\end{tabular}

Data are means \pm standard deviation of duplicate determinations. Means differently super scripted within the columns are significantly different $(\mathrm{P}<0.05)$.

The calcium content of the vegetables ranged between $45.61 \mathrm{mg} / 100 \mathrm{~g}$ and $430.69 \mathrm{mg} / 100 \mathrm{~g}$. The highest value was obtained in bush mallow while African spinach vegetable was the least.

Calcium is one of the most essential macro mineral required by the body for strong teeth and bones and its deficiency is more prevalent than any other mineral. Calcium, phosphorus and vitamin $\mathrm{D}$ help to eradicate rickets in children and osteomalacia as well as osteoporosis among older people [26]. Magnesium content of the vegetables ranged from $11.05 \mathrm{mg} / 100 \mathrm{~g}$ to $198.14 \mathrm{mg} / 100 \mathrm{~g}$. The highest value was obtained in African spinach while garden egg leaf had the least value. The values are within the range reported by Eleazu and Eleazu [21] on the bioactive constituent and in vitro antioxidant capacity of water leaf. Magnesium functions as an activator of ATPs requiring enzymes such as hexokinase, phosphatase, alkaline, fructokinase and adenylcyclase. Magnesium plays vital role in the structure and the function of the human body such as the skeleton and muscle. The adult human body contains about $25 \mathrm{grams}$ of magnesium. The potassium content of these vegetables ranged from $49.82 \mathrm{mg} / 100 \mathrm{~g}$ to $708.28 \mathrm{mg} / 100 \mathrm{~g}$. The highest value occurred in garden egg leaf, while the least value was observed in African spinach. These values are within the range reported by Javed et al. [29] in some selected vegetables grown in Pakistan. Potassium is an intercellular salt that can combine with sodium to influence osmotic pressure and contributes to normal $\mathrm{pH}$ equilibrium in the body [26]. Also, the sodium content of these vegetables ranged from $2.36 \mathrm{mg} / 100 \mathrm{~g}$ to $22.98 \mathrm{mg} / 100 \mathrm{~g}$. Garden egg leaf had the highest value while bush mallow had the least value. Sodium plays a significant role in the maintenance of osmotic pressure of the body fluids. Sodium is one of the minerals whose absorption is considered a factor in the etiology of hypertension hence, its low availability in these vegetables can lower the incidence of hypertension. The result obtained in this study is similar to previous reports on some other species of Nigerian vegetables [30, 31]. Of note, the highest concentration of mineral in these vegetables are calcium and potassium and the results further indicate that these vegetables can contribute significantly to the mineral nutrition of the consumers. 


\section{Anti-nutritional content of vegetables}

Table 5. Antinutrient composition of vegetables $(\mathrm{mg} / 100 \mathrm{~g})$

\begin{tabular}{lcccc}
\hline Sample & Phytate & Oxalate & Tannin & Saponnin \\
\hline Bush mallow & $3.04 \pm 0.02^{\mathrm{a}}$ & $0.80 \pm 0.01^{\mathrm{a}}$ & $0.10 \pm 0.01^{\mathrm{c}}$ & $0.16 \pm 0.02^{\mathrm{d}}$ \\
Garden egg leaf & $1.94 \pm 0.06^{\mathrm{b}}$ & $0.72 \pm 0.02^{\mathrm{b}}$ & $1.01 \pm 0.01^{\mathrm{a}}$ & $0.31 \pm 0.01^{\mathrm{c}}$ \\
African spinach & $0.47 \pm 0.03^{\mathrm{d}}$ & $0.63 \pm 0.02^{\mathrm{c}}$ & $0.48 \pm 0.01^{\mathrm{b}}$ & $2.56 \pm 0.01^{\mathrm{a}}$ \\
Bush okro & $1.32 \pm 0.03^{\mathrm{c}}$ & $0.66 \pm 0.01^{\mathrm{d}}$ & $0.53 \pm 0.03^{\mathrm{b}}$ & $1.68 \pm 0.02^{\mathrm{b}}$
\end{tabular}

Data are means \pm standard deviation of duplicate determinations. Means differently super scripted within the columns are significantly different $(\mathrm{P}<0.05)$

The mean values of the anti-nutritional content of the vegetables are presented in table 5.

The phytic acid content ranged from $1.94 \mathrm{mg} / 100 \mathrm{~g}$ to $3.0 \mathrm{mg} / 100 \mathrm{~g}$. The highest value was obtained in bush mallow while the lowest value was in African spinach. Our findings are within the range reported by Akubugwo et al. [25] on Amaranthus hybridus. Phytic acid is a strong chelating agent that can form protein and mineral-phytic acid complex, thereby reducing protein and mineral bioavailability. The saponin content of these vegetables ranged from $0.16 \mathrm{mg} / 100 \mathrm{~g}$ to $2.56 \mathrm{mg} / 100 \mathrm{~g}$. These values are lower than the finding of Nkafamiya et al. [32]. Saponins are glycosides containing polycyclic aglycone moiety of either $\mathrm{C}_{27}$ steroid or $\mathrm{C}_{30}$ triterpenoids attached to a carbohydrate. High saponin level has been associated with gastroenteritis manifested by diarrhea and dysentery [33]. It is also associated with cholesterol lowering activities [34]. The tannins contents of the vegetables varied from $0.10 \mathrm{mg} / 100 \mathrm{~g}$ to $1.01 \mathrm{mg} / 100 \mathrm{~g}$. The highest value was recorded in garden egg leaf and the least value in bush mallow. Tannins prevent the activities of digestive enzymes such as trypsin, chymotrypsin, amylase and lipase. The tannin-epigallo-catechin3-gallate is known to possess hypoglycemic activity [21]. The concentration of these phytochemicals in these vegetables is not high as to constitute health hazard, since they are within safe level.

The oxalate content of these vegetables ranged from $0.63 \mathrm{mg} / 100 \mathrm{~g}$ to $0.8 \mathrm{mg} / 100 \mathrm{~g}$. The highest oxalate content was obtained in bush mallow, while the least was in African spinach. Oxalate renders calcium unavailable by binding to the calcium ion complex $[35,36]$. Anti-nutrients limit the use of many plant foods due to their occurrence as natural compounds capable of eliciting deleterious effect in man and animals [37]. However, the values recorded in this study were far below the toxic level and cannot cause harm in the vegetables when consumed.

\section{Conclusion}

The chemical and phytochemical compositions of some commonly consumed vegetables in Nigeria are highlighted. These vegetables contain macro and micronutrients especially protein, calcium, magnesium, potassium, vitamins $\mathrm{A}$ and $\mathrm{C}$, riboflavin, thiamin and niacin in high concentrations. These were specific for protein in Garden egg leaf, in African spinach and Bush mallow, crude fibre in African spinach and ash in Garden egg leaf. For vitamins and minerals, vitamin A was high in Garden egg leaf and African spinach, riboflavin in Bush mallow and Garden egg leaf, while vitamin $\mathrm{C}$ was high in all these vegetables. These vegetables do not only have the potential to supply enough nutrients to consumers, but can also contribute to dietary fibre and antioxidant compounds for boosting human immunity. The relative low level of phytochemicals in these vegetables will not hamper mineral absorption and utilization in the body. Therefore, the consumption of these vegetables which are relatively cheap and readily available during the rainy season must be encouraged to maintain balanced nutrition and improve human health. The data of the nutrients recorded in this study can be used for food composition table to improve human health 
and ameliorate hidden hunger, especially among the low income groups and rural population. Further research on the bioactive compounds in these vegetables will be undertaken to complement the results obtained in this study towards their nutritional and health benefits.

\section{Conflict of Interest}

The authors declare that there is no conflict of interest.

\section{References}

[1] J. Omale, C.E. Ugwu, Comparative studies on the protein and mineral composition of some selected Nigerian vegetables, Afr. J. Food Sci. 5 (1) (2011) 22-25.

[2] A.I. Ihekoronye, P.O. Ngoddy, Integrated Food Science and Technology for the Tropics, Macmillan Publishers, New York (1985) 296-301.

[3] Y. A. Iyaka, Concentration of $\mathrm{Cu}$ and $\mathrm{Zn}$ in some fruits and vegetables commonly available in North central Zone of Nigeria. EJEAFCHE 6(6) (2007) 2150-2154.

[4] N. J. Enwere, Foods of plant origin, Nigeria Afro-Orbis Publications Ltd (1998) 293.

[5] T. Oguntona, in: A.U. Osagie, O.U. Eka (Eds), Nutritional quality of plant foods, Nigeria Post Harvest Research Unit (1998) 133.

[6] S.S. Sobowale et al., Effect of preservation methods and storage on nutritional quality and sensory properties of leafy vegetables consumed in Nigeria, J. Med. And Applied Bioscience 2 (2010) 46-56.

[7] G.D. Pamplama-Roger, Healthy foods, Canada, Spain, Editorial Safeliz, 2006.

[8] AOAC, Official method of Analysis $18^{\text {th }}$ Ed. Association of Official Analytical chemists Washington D. C. (2006) 106.

[9] J.K. Kanu, E.H. Sandy, B.A.J. Kandeh, Production and evaluation of breakfast cereal-based porridge mixed with sesame and pigeon peas for adults, Pak. J. Nutr. 8 (9) (2009) 1335-1343.

[10] S.C. James, Analytical chemistry of food, Chapman and Hill printers London (1995) 25.

[11] D. Oberlease, Phytates, in: Toxicants occurring in natural foods, (Strong F. ed.). National Academy of Sciences, Washington DC, 1973, pp. 363-370.

[12] B.O. Obodani, P.O. Ochuka, Phytochemical studies and comparative efficacy of the crude extracts of some Homeostatic plants in Edo and Delta States of Nigeria, Global J. Pure Applied Sci. 8 (2) (2001) 203-208.

[13] D. Pearson, Chemical Analysis of Food, Churchill Livingston, Edinburg, UK. (1976) 103110.

[14] C.I. Iwuoha, F.A. Kalu, Calcium oxalate and physicochemical properties of cocoyam: Colocasia and Xanthosoma sagitifolium tuber flours as affected by processing, Food Chem. 54 (1995) 61-66.

[15] B.M. Ogle, L.E. Grivetti, Legacy of the chameleon, Edible wild plants in the kingdom of Swaziland, South-Africa, A cultural ecological nutrition study. Part IV: Nutritional analysis and conclusion, Ecological Food Nutr.17 (1985) 41-64.

[16] U. Isong, U.I. Idiong, Comparative studies on the nutrition and toxic composition of three varieties of Leianthera Africana, Plant Food Hum. Nutr. 51 (1997) 79-84.

[17] L.G. Hassan, K.J. Umar, Nutritional value of Balsam apple (Momordica balsamina L) leaves, Pak. J. Nutr. 5(6) (2006) 522-529.

[18] A.A. Akindahunsi, S.O. Salawu, Phytochemical screening and nutrient- anti nutrient composition of selected tropical green vegetables, Afr. J. Biotechnology 4 (2005) 497-501. 
[19] B.S. Anita et al., Nutritive and anti-nutritive evaluation of sweet potatoes (Ipeomea batatas) leaves, Pak. J. Nutr. 5 (2006) 166-168.

[20] S. Henry, Fiber: an all-natural "medicine" for type 2 diabetes? Consumer's health interactive, 2004. Available: http://www.ahealthyme.com.

[21] C.O. Eleazu, K. C. Eleazu, Bioactive constituent and in vitro antioxidant capacity of water leaf (Talinium triangulare) as affected by domestic cooking, European J. Medicinal Plants 3(4) (2013) 540-551.

[22] A.A.J. Mofunanya et al., Comparative study of the effect of organic and inorganic fertilizer on nutrient composition of Amaranthus spinosus L, Asian J. Plant Sci. 14(1) (2015) 34-39.

[23] D.E. Okwu, C. Josiah, Evaluation of the chemical composition of two Nigerian medical plants, Afr. J. Biotechnology 5(4) (2006) 357-361.

[24] A.R. Roth, C.E. Townsend, Nutrition and diet therapy, $8^{\text {th }}$ edition.Delmar Learning, Thomason Learning Inc, Canada (2003) 150-153.

[25] I.E. Akubugwo et al., Nutritional and chemical value of Amaranthus hybridus L, Afr. J. Biotechnology 6(24) (2007) 2833-2839.

[26] D.E. Okwu. M.E. Okwu, Chemical composition of Spondias mombim Linn plant parts, J. Sustainable Agric. and Environment 6 (2004)140-147.

[27] E.T. Ifon, O. Bassir, The nutritive value of some Nigeria leafy vegetables, Part 1, vitamins and minerals, Food Chem. 4 (1979) 263-267.

[28] E.I .Adeyeye, O.O. Agesin, Dehulling the African yam bean (Sphenostylis stenocarpa Hoscst ex. A. ich) seeds: Any nutritional importance?, Bangladish J. Sci. Ind. Research. 42 (2007) 163-174.

[29] A. Javed et al., Proximate composition, minerals and vitamins content of selected vegetables grown in Peshawear, J. Chem. Society Pak. 33 (1) (2011) 118-122.

[30] Z.P. Joshua, A.G. Timothy, M.M. Suleiman, The effect of cooking time on the vitamin C and mineral composition of some local vegetables, Sci. World J. 7(1) (2012) 29-30.

[31] H.D. Mepha, L. Eboh, D.E.B. Banigo, Effects of processing treatments on the nutritive composition and consumer acceptance of some Nigerian edible leafy vegetables, African J. Food, Agric., Nutr. \& Development 7 (10) (2007)1-18.

[32] I.I. Nkafamiya et al., Nutrient content of seeds of some wild plants, Afr. J. Biotechnology 6 (14) (2007) 1665-1669.

[33] I.S. Awe, O.A. Sodipo, Purification of saponins of root of Blighia sapida Koenlg-Holl. Nig. J. Biochem. Molecular Biology 16 (37) (2001) 201-204.

[34] C.O. Eleazu, P.N. Okafor, I. Ahamefuna, Total antioxidant capacity, nutritional composition and inhibitory activity of unripe plaintain (Musa paradisiacae) on oxidative stress in alloxan induced diabetic rabbit, Pak. J. Nutr. 9 (11) (2010) 1052-1057.

[35] O. Ladeji, C.U. Akin, Umaru, A study of cyanogenetic glucoside contents of some edible nuts and seeds. Journal of Chemical Society of Nigeria, 31 (1-2) (2004) 12-14.

[36] I.I. Nkafamiya, A.G. Manyi, A study of cyanogenic glucoside contents of some edible nuts and seeds, Afr. J. Biotechnology. 6(14) (2006) 1665-1669.

[37] D. Kubmarawa, I.F.H. Andenyand, A.M. Magomya, Amino Acid Profile of two - non conventional leafy vegetable: Sesanum and Balanite saegyptiaca, Afr. J. Biotechnology (19) (2008) 3502-3504. 